Gabriel Arcanjo Santos de Albuquerque

\title{
O ESTADO DA ARTE DAS PESQUISAS SOBRE PAULO JACOB E A SUA FICÇÃO
}

\section{THE STATE OF THE ART OF RESEARCH ON PAULO JACOB AND HIS FICTION}

\section{EL ESTADO DEL ARTE DE LA INVESTIGACIÓN SOBRE PAULO JACOB Y SU FICCIÓN}

\author{
Jamesclay Almeida de Souza $a^{1}$ \\ Universidade Federal do Amazonas (UFAM) \\ Karina Marques ${ }^{2}$ \\ Universidade de Poitiers \\ Gabriel Arcanjo Santos de Albuquerque ${ }^{3}$ \\ Universidade Federal do Amazonas (UFAM)
}

\begin{abstract}
Resumo: Neste artigo buscamos levantar o estado da arte das pesquisas sobre a obra do escritor amazonense Paulo Jacob, constituída por 15 volumes ainda escassamente conhecidos e estudados, ainda que reconhecidos por sua importância cultural e qualidade literária. $\mathrm{O}$ objetivo é descobrir respostas para as seguintes perguntas: qual interesse particular desperta a obra jacobiana? Quais são os estudos considerados pioneiros? Qual é o tipo de pesquisa que está sendo produzida? Por quem, onde e quando? As pesquisas nessa área vêm crescendo ou diminuindo nos últimos anos? O que há ainda por estudar?
\end{abstract}

Palavras-chave: Paulo Jacob; Escritor judeu; Literatura amazônica.

Abstract: In this article we seek to raise the state of the art of research on the work of the Amazonian writer Paulo Jacob, consisting of 15 volumes still sparsely known and studied, even though recognized for its cultural importance and literary quality. The aim is to find answers to the following questions: What particular interest does the Jacobian work arouse? What are the pioneering studies? What is the type of research being produced? By whom, where and when? Has the research in this area been increasing or decreasing in recent years? What is there to study?

Keywords: Paulo Jacob; Jewish writer; Amazon Literature.

Resumen: En este artículo buscamos elevar el estado de la investigación sobre la obra del escritor amazónico Paulo Jacob, que consta de 15 volúmenes aún escasamente

\footnotetext{
${ }^{1}$ Mestre em Letras - Estudos Literários pela Universidade Federal do Amazonas. Doutorando do Programa de Pós-Graduação Sociedade e Cultura na Amazônia. E-mail: jamescleya@ gmail.com

2 Professora doutora (maître de conférences) na Universidade de Poitiers, França. E-mail: karina.marques@univ-poitiers.fr

${ }^{3}$ Doutor em letras e professor da Universidade Federal do Amazonas (Ufam), Manaus, AM, Brasil. Email: g_albuquerque@ufam.edu.br
} 
Gabriel Arcanjo Santos de Albuquerque

conocidos y estudiados, aunque reconocidos por su importancia cultural y calidad literaria. El objetivo es encontrar respuestas a las siguientes preguntas: ¿Qué interés particular despierta la obra jacobiana? ¿Cuáles son los estudios considerados pioneros? ¿Qué tipo de investigación se está produciendo? ¿Por quién, dónde y cuándo? ¿La investigación en esta área ha estado creciendo o disminuyendo en los últimos años? ¿Qué hay que estudiar todavía?

Palabras clave: Paulo Jacob; Escritor judio; Literatura amazónica.

\section{INTRODUÇÃO}

É considerado ponto assente que pesquisas que levam a denominação de "estado da arte" ou, ainda, de "estado do conhecimento" são uma etapa fundamental em todo e qualquer trabalho científico. Pela sua própria natureza, avaliadas como sendo de caráter bibliográfico, elas se caracterizam por apresentar a seguinte função: "o desafio de mapear e de discutir uma certa produção acadêmica em diferentes campos do conhecimento, tentando responder que aspectos e dimensões vêm sendo destacados e privilegiados em diferentes épocas e lugares, de que forma e em que condições têm sido produzidas" (FERREIRA, 2002, p. 258). Elas trazem embutida a ideia de inventário e de sistematização de dados em uma dada área do conhecimento.

Em nosso caso, em particular, a área de conhecimento sobre a qual iremos nos debruçar é a ficção do escritor amazonense Paulo Jacob (1921-2003), que também foi magistrado, professor universitário, membro da Academia Amazonense de Letras, do Instituto Histórico e Geográfico e da Associação de Escritores do Amazonas. Sendo um dos mais fecundos romancistas da Amazônia, a sua obra é formada por uma plêiade de 15 volumes $^{4}$, escritos ao longo de uma carreira literária de quase quatro décadas, indo de 1964 a 1999. Trata-se de uma obra com variada temática, indo do destaque à cultura indígena, passando por questões ambientais e socioculturais que marcam a região, contribuindo, inclusive, aos estudos linguísticos do falar regional amazônico.

\footnotetext{
${ }^{4}$ Muralha verde (1964); Andirá (1965); Chuva branca (1968); Dos ditos passados nos acercados do Cassianã (1969); Chãos de Maíconã (1974); Vila rica das queimadas (1976); Estirão de mundo (1979); A noite cobria o rio caminhando (1983); Dicionário da língua popular da Amazônia (1985); O gaiola tirante rumo do rio da borracha (1987); Um pedaço de lua caía na mata (1990); O coração da mata, dos rios, dos igarapés e dos igapós morrendo (1991); Amazonas, remansos, rebojos e banzeiros (1995); Assim contavam os velhos índios ianõnãmes (1995) e Tempos infinitos (1999).
} 
Jamesclay Almeida de Souza

Karina Marques
Geografia, Literatura e Arte, v.1, n.2, p. 172-200, jul./dez.2018

DOI: 10.11606/issn.2594-9632.geoliterart.2018.174373

Gabriel Arcanjo Santos de Albuquerque

Nossa proposta, neste trabalho, é mapear e discutir - ainda que de forma não exaustiva - a produção sobre esse conjunto de 15 volumes que formam o que aqui chamamos de obra jacobiana, com o objetivo de descobrir quantas e quais são as pesquisas, contrapontos, citações ou referências feitas sobre essa área. Mais especificamente, o que pretendemos saber sobre esse campo é: qual interesse desperta tal objeto de estudo? Quais são os estudos pioneiros? Qual é o tipo de pesquisa que está sendo produzida? Por quem, onde e quando? Houve um aumento de interesse pela obra do escritor, nos últimos anos, por parte dos pesquisadores? O que há ainda por pesquisar? Por fim, a realização deste estado da arte vai nos levar a um objetivo maior: a difusão, a valorização e a preservação da obra jacobiana, ainda escassamente conhecida e estudada, não obstante o seu reconhecido valor cultural e qualidade literária.

Quanto à metodologia utilizada em nosso trabalho, trata-se de uma pesquisa de natureza mista, ou seja, quali-quantitativa, com uma parte constituída por descrição e interpretação e outra por tabulações numéricas, com o objetivo de obter uma compreensão mais ampla do tema estudado. Para a revisão bibliográfica, foram realizadas buscas pelo termo "Paulo Jacob" ou o nome de seus romances, em jornais, volumes publicados sobre a literatura amazônica e estudos específicos sobre o autor e a sua obra, em formato físico, e, pontualmente, em sites de literatura. Buscas focadas em uma produção científica mais recente foram realizadas em plataformas internacionais de divulgação científica, tais como o Google Acadêmico, e nacionais, como o banco de dados da Coordenação de Aperfeiçoamento de Pessoal de Nível Superior (CAPES). Por fim, podemos mencionar como fonte de pesquisa a correspondência do escritor, na qual também encontramos uma crítica valiosa sobre a sua obra.

O recorte temporal estabelecido foi o ano de 1964 ao ano 2019, isto é, da publicação de Muralha verde, aos dias atuais, em que se comemora os 20 anos de publicação de seu último romance, Tempos infinitos (1999). Nossas buscas nos sites Google Acadêmico e Banco de Dados da CAPES encontraram 52 arquivos relacionados, direta ou indiretamente, a Paulo Jacob e ao conjunto de 15 volumes que formam a sua obra. À parte dessa busca eletrônica, encontramos ainda 3 livros, uma dissertação, uma antologia em formato físico e uma carta enviada ao escritor, cujos 
Jamesclay Almeida de Souza

Karina Marques
Geografia, Literatura e Arte, v.1, n.2, p. 172-200, jul./dez.2018

DOI: 10.11606/issn.2594-9632.geoliterart.2018.174373

Gabriel Arcanjo Santos de Albuquerque

trechos estão publicados na orelha de um de seus livros. Todos eles foram igualmente arrolados nesse corpus, totalizando, ao final, 58 objetos de estudo. Em linhas gerais, todas essas publicações se enquadram em um destes dois grupos: pesquisas ou textos diversos que tratam de forma exclusiva sobre o autor e a sua obra; ou trabalhos que podem ser classificados como contrapontos, citações ou referências feitas a eles.

Agrupando as 58 publicações pela categoria tipo, como fizemos no gráfico abaixo, elas totalizaram 13 subgrupos, com seus respectivos números:

Figura 1: Tipo de publicação/pesquisa produzida sobre Paulo Jacob e a sua ficção.

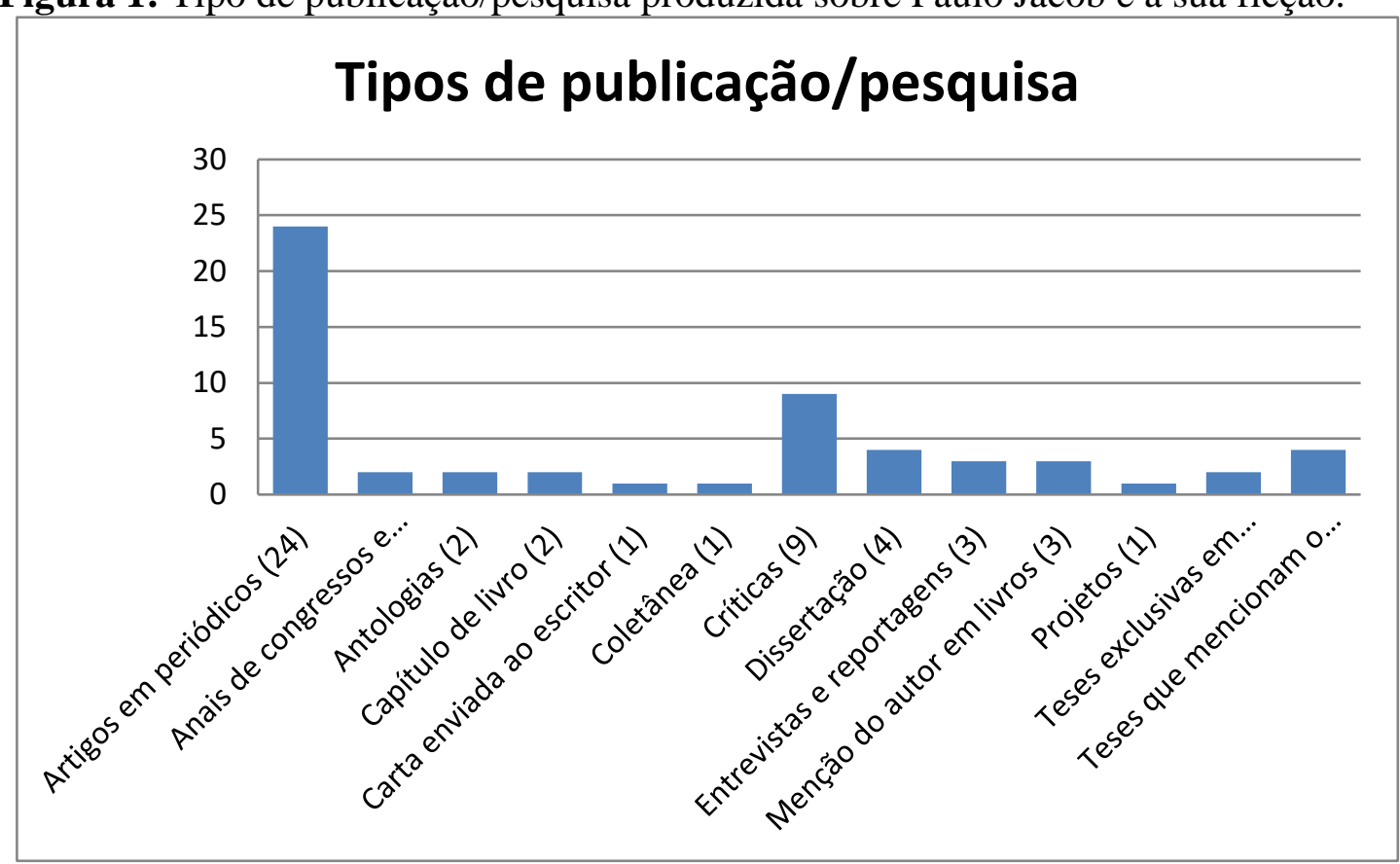

Fonte: elaborado pelos autores.

Como é possível observar, as três principais publicações que têm sido produzidas sobre Paulo Jacob e a sua ficção são, pela ordem, artigos em periódicos, críticas e teses que fazem referências a eles, com destaque para o primeiro subgrupo, que compreende quase metade de todas as produções. Importa sublinhar, aqui, a diversidade desses textos, os quais vão de matérias de cunho jornalístico, passando por trabalhos editoriais que reúnem autores selecionados, bem como por rápidas referências em livros, e chegando a trabalhos acadêmicos de maior complexidade, como os que apresentam e discutem ideias - artigos científicos - e aqueles que apresentam o 
Jamesclay Almeida de Souza

Karina Marques
Geografia, Literatura e Arte, v.1, n.2, p. 172-200, jul./dez.2018

DOI: 10.11606/issn.2594-9632.geoliterart.2018.174373

Gabriel Arcanjo Santos de Albuquerque

resultado de uma investigação mais ampla e aprofundada, como é o caso das teses e dissertações.

Como falaremos das teses que fazem referência ao nosso objeto mais adiante, é oportuno salientar aquelas que ainda não foram publicadas, ou seja, que são pesquisas em andamento. Nossas buscas tomaram ciência de duas teses de doutorado que estão em desenvolvimento, ambas pelo Programa de Pós-Graduação Sociedade e Cultura na Amazônia (PPGSCA), ligado à Universidade Federal do Amazonas (UFAM). A primeira é de Joaquina Maria Batista de Oliveira, e a segunda é de Jamescley Almeida de Souza. Esta tem como título provisório "A Amazônia ficcional de Paulo Jacob: uma perspectiva da geografia cultural", e tem como objetivo mostrar qual foi a Amazônia que o escritor representou; já aquela se intitula "O rio caudaloso da consciência: vozes e espaços subalternos da Amazônia na produção literária de Paulo Jacob”, trabalhando com o conceito de subalternidade na região em questão. Ambas são orientadas por Gabriel Arcanjo Santos de Albuquerque, professor do programa.

É de grande interesse esclarecer, ainda, duas diferenças quanto a alguns subgrupos apresentados no gráfico acima. A primeira diz respeito aos livros e capítulos de livro, os quais se distinguem pelo seguinte: esses últimos se referem a trabalhos que expõem análises de algum romance de Paulo Jacob e são publicados, em conjunto com artigos diversos, por organizadores; já os primeiros estão relacionados a livros sobre a literatura produzida no Amazonas e que mencionam o autor, mesmo que de modo breve. Ambos serão comentados mais adiante. A segunda é a diferença que usamos aqui entre coletânea e antologia: esta engloba duas publicações feitas pela Academia Amazonense de Letras, contemplando vários de seus imortais, entre eles Paulo Jacob; e aquela se resume a uma coletânea de diversas fontes de informação, a qual cita um dicionário publicado pelo autor como uma referência de gíria regionalista da Amazônia.

Essa coletânea se trata da Introdução às fontes de informação, dos organizadores Bernadete Campello e Paulo Caldeira. A autora do capítulo que versa sobre dicionários, Vera Macedo, ressalta que "os dicionários de gíria e de regionalismos registram os termos usados na linguagem coloquial ou popular por certos grupos sociais (policiais, estudantes etc.) ou por habitantes de uma determinada região" (MACEDO, 2008, p. 35), 
Gabriel Arcanjo Santos de Albuquerque

e aí cita o Dicionário da língua popular da Amazônia (1985), de Paulo Jacob, publicado pela editora Cátedra.

De outra parte, as duas antologias têm como autores dois membros da Academia Amazonense de Letras. A primeira, intitulada Imponderável silêncio (2011), é de Armando Menezes, o qual foi amigo de Paulo Jacob. No livro, o também imortal da academia, além de trazer uma fotografia de rara disponibilidade do escritor, discorre, em 14 páginas, sobre o itinerário de vida profissional, intelectual e artística do colega de academia: as origens, a liderança, o comprovado conhecimento na língua tupi, as premiações que ele ganhou, o elogio de grandes escritores, bem como conquistas da vida pessoal. Chamamos atenção para o determinado momento em que, avaliando sobre a base das produções ficcionais de Paulo Jacob, Armando Meneses declara:

Seus romances baseiam-se em histórias e lendas de origem do meio hinterlandino amazônico, num linguajar simples, igual ao do nosso caboclo, com o objetivo maior de projetar sempre as figuras do pescador, do caçador, do seringueiro, do agricultor, do artesão e, igualmente, da mulher, sem a qual esses bravos e heroicos homens nada conquistariam na vida (MENEZES, 2011, p. 66).

Já a segunda, uma compilação de poesias, prosas, músicas, parlendas, teatros etc, é de autoria de Zemaria Pinto e tem como título Ensaios ligeiros (2014). No livro, na parte que leva o nome de "Uns dedos de prosa", há um ensaio chamado "Em memória de Paulo Jacob". Ensaios ligeiros faz parte das publicações da Secretaria de Cultura do Estado do Amazonas e foi prefaciado pelo então governador José Melo.

\section{AS PRIMEIRAS CRÍTICAS E ESTUDOS ACADÊMICOS}

Paulo Jacob teve alguns dos seus romances galardoados com o prêmio Walmap (1964-75), o maior prêmio literário da época: Chuva branca, 1967, 4º lugar; Dos ditos passados nos acercados do Cassianã, 1969, 2 lugar; e Vila Rica das Queimadas, 1976, $2^{\circ}$ lugar. O marco-inicial dos estudos sobre a obra jacobiana pode ser considerado o texto do crítico e escritor piauiense Assis Brasil, publicado em 1968, no jornal carioca Correio da manhã (1901-1974), na sequência da primeira premiação recebida por Paulo Jacob. Teve como alvo, portanto, Chuva branca, romance publicado naquele ano, 
Gabriel Arcanjo Santos de Albuquerque

finalista do Walmap no ano anterior, e que viria a ser considerado como símbolo da proeza estilística e narrativa do autor e principal objeto de estudo sobre a sua obra. Intitulado Por uma linguagem literária, Assis Brasil faz a seguinte declaração: “Chuva branca ficará como um dos melhores romances brasileiros do ano, na área jovem, tão carente de revelações" (BRASIL, 1968, p. 44).

Dentre os quatro finalistas do prêmio, o crítico considera esse romance como o melhor: "sem querer pôr em discussão o julgamento do II Prêmio Walmap. Gostaria de assinalar que entre os romances classificados no concurso e publicados até agora, Chuva branca é, sem dúvida, o melhor” (Ibid., p. 44). E segue Assis Brasil, elogiando a criação linguística do escritor amazonense: "o que Paulo Jacob consegue, mais do que o outro romancista, é criar, dentro desta perspectiva estética, um mundo mais opulento, mais dramático, onde a condição humana recebeu um corte muito mais profundo" (Ibid., p. 44). E finaliza apresentando uma das melhores descrições já feitas sobre esse livro:

Romance mais rico de experiência, Chuva branca rompe com o neonaturalismo de nossos jovens "acadêmicos" e propõe a narrativa, direta, indireta, do ponto-de-vista de um único personagem. $\mathrm{O}$ homem perdido na mata, e a mata se transforma em personagem com seus bichos e plantas. A solidão, os pensamentos, as referências a uma vida que é "padrão brasileiro" nos confins da marginalização social. Paulo Jacob, abolindo a ação episódica e a narrativa linear, faz uma espécie de "sustentação dramática" da sobrevivência do personagem, numa ação interior forte e plenamente realizada (BRASIL, 1968, p. 44).

E Jorge Amado, membro do júri desse primeiro concurso, assim descrevia a obra jacobiana num testemunho epistolar, não datado, em que a admiração pelo futuro amigo se desfralda:

Tomei conhecimento da tua literatura em 1967, quando, com Guimarães Rosa, e Antônio Olinto, fui juiz de um prêmio Walmap e um dos livros premiados foi o belo Chuva Branca de tua autoria. Recordo ainda hoje o entusiasmo de Rosa pelo teu livro, entusiasmo que foi igualmente meu e do Olinto. [...] A grandeza fundamental da obra do Rosa provém da vida que ele criou, do mundo que ele recriou, aquele mundo que fica nas divisas sertanejas de Minas e Bahia [...] a carne e o sangue do homem brasileiro que está em seus livros. $\mathrm{O}$ mesmo pode ser dito a teu respeito. Fala-se muito no trabalho de linguagem efetuado em teus livros, notável sem dúvida na reconstrução de uma língua literária nascida da língua do povo 
Gabriel Arcanjo Santos de Albuquerque

amazônico. Penso contudo que o mais importante na criação da saga jacobiana é a vida, o povo, o homem amazônico em sua verdade, em sua miséria, em sua grandeza que o "juiz das leis" restaura e recria e incorpora à nossa geografia literária (JACOB, 1999, orelha).

Se o Walmap nem sempre premiou Jacob nas posições altaneiras, foram as críticas dele advindas que marcaram a entrada de jure da sua ficção amazônica na "geografia literária" brasileira. Nesse sentido, segundo Jorge Amado, Paulo Jacob e Guimarães Rosa, também membro do júri desse mesmo concurso, partilham a mesma honra e responsabilidade de fincar no corpo literário do seu país a dor universal/nacional do povo de suas regiões.

A importância de Jacob como representante do povo amazônico também foi fato reconhecido pelo escritor e crítico mineiro Antônio Olinto, um dos idealizadores do Walmap e quinto ocupante da cadeira 8 da Academia Brasileira de Letras. Em 1973, falando sobre o prêmio, ele assim afirma: “o Amazonas apareceu no Walmap em muitos romances, tendo Paulo Jacob, escritor de Manaus, tirado menção especial no segundo e o segundo lugar no terceiro" (OLINTO, 1973, n. p.).

Se a premiação da ficção jacobiana no Walmap teve papel fundamental para a descoberta e valorização da literatura amazônica, dentro do panorama literário nacional - ainda que tal incursão não se tenha transformado em presença perene -, tal fato provocou igualmente um recrudescimento do interesse da crítica regional pela obra do seu conterrâneo.

Em 1976, Mário Ypiranga Monteiro, professor, crítico e escritor manauara, conhecido por sua grande contribuição aos estudos sobre a história do Amazonas e a literatura amazonense, menciona Paulo Jacob em oito páginas (págs. 48, 92, 165, 259, 260, 300, 301 e 302). Vemo-nos obrigados a dizer que, entre muitos erros de ortografia, nome de personagens, nome de romance e o próprio nome do escritor ${ }^{5}$, Mário Ypiranga,

\footnotetext{
${ }^{5}$ Os editores de Fatos da literatura amazonense exibem, logo no início, uma errata por meio da qual afirmam: "apesar de todo o cuidado com a revisão escaparam os seguintes erros". De fato, e observando apenas as referências a Paulo Jacob, é possível destacar os que seguem: o nome correto do romance publicado em 1969 é Dos ditos passados nos acercados do Cassianãa, e não Dos ditos e acontecidos nos acercados de Cacianã, como o livro de Ypiranga traz (MONTEIRO, 1976, pp. 48, 260). Outra: o livro grafa o nome do escritor como "Paulo Erban Jacó" (Ibid., pp. 92, 300), quando o correto é Paulo Herban (Maciel) Jacob. Mais: o nome correto do prêmio literário a que Paulo Jacob concorreu por várias vezes foi o Walmap, e não "Valmap" (Ibid., p. 300). E, talvez o mais emblemático dos erros, uma vez que desde
} 
Gabriel Arcanjo Santos de Albuquerque

situando Paulo Jacob no que ele chama de ruralismo, afirma: "Chuva branca, de Paulo Erban Jacó, situado no ruralismo busca um caminho comovente (um caminho novo, uma vanguarda literária) na direção anedótica do hábito normal do indivíduo da região: a caça" (MONTEIRO, 1976, p. 92).

A essa ideia convém acrescentar considerações que o crítico introduz em sua análise em torno de como Paulo Jacob aborda a temática da borracha em Dos ditos passados nos acercados do Cassianã, bem como a crítica a respeito da representação do discurso do índio efetuada pelo escritor em Chãos de Maíconã: "nos nossos dias um romancista aproveitável, Paulo Erban Jacó, prometendo a verdadeira saga indígena, mete na boca do protagonista aquela orgia de metagramas que resulta, mais uma vez, em desagradável solução mimética cujo protótipo ainda é o mineiro Guimarães Rosa" (Ibid., p. 165).

$\mathrm{O}$ aspecto da ficção jacobiana, entretanto, que recebe a maior carga das críticas de Mário Ypiranga é a imitação, por parte de Paulo Jacob, de Guimarães Rosa. Que nos seja permitido expressar que são críticas extensas, ocupando o espaço inteiro das páginas 259 e 301:

Podemos selecionar outro exemplo, mais recente, de equívoco da linguagem de suporte. Paulo Jacob desapercebeu-se de que a prosa insinuante de Guimarães Rosa está saturada de metafisicismo, pelo menos em Grande sertão: veredas, e deixou-se averbar na simpatia pelo estilo pitoresco mas intencionalmente mágico. Se fosse mais arguto aproveitaria com sucesso o estilo magistral em nível de pesquisa e desencantava a rapsódia nativa, que muito se presta a essa colocação (MONTEIRO, 1976, p. 259).

E uma avaliação mais radical ainda:

Pois, Paulo Jacob, contrariando aquele proverbial instrumento de comunicação linguística a que José Veríssimo deu ênfase, supõe muito caroável tanger à frente de seu novo-realismo uma regra que é falsa por muitos motivos: deixou-se averbar na simpatia de Grande sertão: veredas, quando são muito outras as dimensões traçadas entre o

a primeira edição de Chuva branca (1968), o nome de seu protagonista é apresentado como sendo Luis Chato, Mário Ypiranga inventa o João Chato (!): "por isso de autêntico só há na sua obra romanesca a aventura de João Chato em Chuva branca, que escapou sutilmente ao infernismo" (Ibid., p. 301). 
Jamesclay Almeida de Souza

Karina Marques

Gabriel Arcanjo Santos de Albuquerque

sertanismo sulino e o ruralismo amazônico (MONTEIRO, 1976, p. $301)$.

Em 1978, apresentando Dalcídio Jurandir como o maior nome do romance amazônico, o poeta e ensaísta acreano Jorge Tufic assenta Paulo Jacob ao lado desse escritor paraense: "ao seu lado, porém, vêm agora de colocarem-se [...] 'Chuva branca' e outros, de Paulo Jacob" (TUFIC, 1978, p. 6). Já Márcio Souza, célebre escritor e intelectual também de Manaus, contrapõe-se à opinião de seus colegas, classificando o seu estilo como hermético, a sua linguagem como "caudalosa, intrincada, como uma torrente de galhos" (SOUZA, 1978, p. 194).

Quanto à primeira pesquisa acadêmica sobre a obra jacobiana, publicada de forma vanguardista ainda em 1990, ela destaca o olhar inovador de Jacob sobre os problemas sociais do homem amazônico. Antônio Esteves, nessa dissertação de mestrado defendida pela Universidade Estadual Paulista (UNESP), realiza um estudo sobre a literatura amazonense em Chuva branca, muito embora aborde, de forma geral, todos os romances de Paulo Jacob publicados até então: nove, no total. De Chuva branca, em particular, Esteves diz, vinte e dois anos após a sua publicação: "pela primeira vez, uma reflexão séria e bem construída do caboclo amazonense e suas relações com o meio que o cerca" (ESTEVES, 1990, p. 75).

Podemos constatar, portanto, que foi o grande prêmio literário Walmap que projetou a obra jacobiana para além de seus limites regionais, apontando para a sua integração dentro do cânone literário brasileiro, objetivo que não chegou a ser conquistado (a linguagem hermética do autor, o uso de termos regionalistas, o pouco interesse dos leitores pelos temas amazônicos, o desnível de sua produção literária e até mesmo a falta de visibilidade do escritor dentro da cena literária das grandes capitais são cogitados como possíveis explicações para esse fato). Se logo nos anos subsequentes à premiação de Chuva Branca, críticos influentes no cenário literário nacional reconheceram o valor cultural e estético desse romance; num segundo momento, foram sobretudo os estudiosos da região norte do país que lançaram um olhar mais abrangente e contextualizado sobre a sua obra, tocados por um compromisso intelectual e humano em valorizar a produção dos homens de sua terra. Com relação à primeira pesquisa acadêmica realizada sobre o autor, ela prenuncia, de forma acertada, o 
Gabriel Arcanjo Santos de Albuquerque

interesse que viria mais tarde a despertar a obra jacobiana, tanto no meio acadêmico nacional quanto internacional, em razão do olhar profundo e, em muitos pontos, inovador que o escritor lança sobre o que Djalma Batista chamou de "complexo amazônico" (BATISTA, 1976).

\section{PRINCIPAIS AUTORES E ENFOQUES}

O meio acadêmico, a partir sobretudo dos anos 2000, foi responsável por estudos abundantes e aprofundados da obra jacobiana, valorizando-a e salvaguardando-a do esquecimento coletivo, após a fase áurea dos galardões do Walmap. Se a produção jacobiana interessou, inicialmente, a um pesquisador de uma universidade paulista (Esteves, 1990), ela foi, posteriormente, alvo de interesse mais alargado, em razão da universalidade da Amazônia como temática; da pluralidade de assuntos importantes abordados; da inovação quanto ao uso do falar regional amazônico no tecido narrativo; e da própria biografia desse autor de origem judaica sefardita, cuja família marroquina instalou-se em Manaus no início do século XX (dentre os autores que mais publicaram sobre a obra jacobiana, e de forma mais aprofundada, encontram-se Souza, da Universidade Federal do Amazonas, com 10 artigos - incluindo autoria única e coautoria -; Marques, da Universidade de Poitiers, França, com 4 artigos; Igel, da Universidade de Maryland, EUA, e Pinto, escritor e antigo professor da Universidade Federal do Amazonas, ambos com 3 publicações).

Desses 4 autores, aquela que há mais tempo publica sobre a área é Regina Igel, doutora em Língua Portuguesa (University of New Mexico) e, atualmente, professora titular da University of Maryland. Pesquisadora com ênfase em literatura brasileira judaica, Igel publicou um boletim, um artigo e um capítulo de livro - esses dois últimos em inglês - sobre Paulo Jacob. O primeiro deles, em 2002, foi o capítulo intitulado "Novels", para o Handbook of Latin American studies, publicado pela editora da Universidade do Texas a pedido da Divisão Hispânica da Biblioteca do Congresso Americano. Nele, ao comentar sobre o romance contemporâneo brasileiro, Igel afirma: 
Gabriel Arcanjo Santos de Albuquerque

o qual retrata o rio Amazonas, sua população cabocla e as maravilhas naturais da área; o outro é Como se faz um guerrilheiro, de Benedicto Monteiro, no qual o protagonista ostenta a sua virilidade ${ }^{6}$ (IGEL, 2002, p. 639, tradução nossa).

Na segunda publicação, vinda em 2012, Igel menciona Paulo Jacob ao tecer considerações em torno das semelhanças e diferenças existentes entre Moacyr Scliar e Milton Hatoum, respeitantes à inclusão de elementos globais e regionais em suas obras literárias. Atentemos à reflexão da pesquisadora:

O quanto tem isso de "regionalismo", tem também de universal. Como os escritores que são rotulados como "regionalistas", e assim passaram para a posteridade (Graciliano Ramos, Érico Veríssimo, Rachel de Queiroz, Paulo Jacob), o manauara Hatoum ancorou sentimentos e obsessões humanas de caráter universal em pessoas e conflitos inerentes à região onde nasceu e cresceu (IGEL, 2012, p. 4, grifo nosso).

Já a sua terceira publicação é uma espécie de boletim, publicado para a Associação Scholem Aleichem (ASA), do Rio de Janeiro, no qual ela faz uma breve análise do romance $O$ judeu mestiço (2012), de Frederico Veiga:

Antes de Frederico Veiga, alguns escritores não judeus marcaram a presença de judeus na região amazônica, como Paulo Jacob (19212004), em Um pedaço da lua caía na mata (1990). Nesse romance, a Amazônia emerge em toda sua exuberância, e o isolamento sofrido por uma família judaica tem a ver tanto com sua religião quanto com as circunstâncias restritas da floresta (IGEL, 2013, n. p.).

É necessário ressaltar três pontos nos trabalhos de Igel sobre Paulo Jacob. Primeiro, não podemos desconsiderar a relação que a autora possui com a cultura judaica no Brasil, em especial com a sua literatura, tendo analisado e ajudado a difundir escritores com essa origem. Segundo, essa divulgação feita por ela, como vemos em relação a Paulo Jacob, acontece em inglês, ou seja, por meio daquela que hoje é considerada língua franca. E, terceiro, dois pequenos equívocos cometidos por Igel:

\footnotetext{
6 "Two new novels offer further literary explorations of the Amazon region: Paulo Jacob's Amazonas, remansos, rebojos e banzeiros, which depicts the Amazon river, its caboclo population, and the natural wonders of the area, and Benedicto Monteiro's Como se faz um guerrilheiro, in which the protagonist boasts of his virility".
} 
Gabriel Arcanjo Santos de Albuquerque

Paulo Jacob não faleceu em 2004, como aponta a autora, mas, sim, no dia nove de abril de $2003^{7}$. E mais: no artigo supracitado, Igel insere o romancista entre os "escritores não judeus", mas a própria viúva dele, dona Marilda, ratifica a sua origem judaica: "ele era católico praticante, mas descendente de judeu, por isso conhecia todo o ritual do Santuário, as festas, as tradições, as datas importantes e ele pesquisava muito também” (BENTES, 2015, p. 119).

O mesmo erro concernente à data de falecimento de Paulo Jacob foi cometido por Souza, estudioso que mais tem se consagrado à obra do escritor. No artigo Paulo Jacob: uma fortuna crítica (2015), o autor também afirma que a data de falecimento do romancista é 2004, quando o correto é 2003. Outro equívoco empreendido por Souza, nessa fortuna crítica, é apontar que o escritor possui "14 romances publicados" (SOUZA, 2015a, n. p.), o que não é verdade: a obra de Paulo Jacob é constituída por 13 romances, uma compilação de lendas e um dicionário. À parte disso, o trabalho traz informações consideráveis sobre o perfil do ficcionista, além de resumos concisos de todos os 13 romances e também as críticas recebidas.

Ainda em 2015, à luz da teoria geral do imaginário, de Gilbert Durand, Souza publicou o artigo Personagens do imaginário ribeirinho no romance Chuva branca, por meio do qual falou do curupira, do mapinguari, da mãe-da-mata e do veado aianga, mitos presentes nessa ficção de Paulo Jacob. Para o autor, "a narrativa de Chuva branca revela que a chamada Terceira Amazônia é um mundo onde ainda é poderosa a mistura entre pensamento racional e pensamento mítico, tal como o era no princípio da reflexão filosófica" (SOUZA, 2015b, p. 115). Dito de outro modo, mito e realidade, nesse espaço, são intercambiáveis.

Trabalhando ainda com o romance Chuva branca (1968), Souza publica mais dois artigos no ano seguinte: Da questão de gênero no romance Chuva branca e Do sagrado na Terceira Amazônia: um olhar a partir do romance Chuva branca. No primeiro, Souza explora o discurso em forma de monólogo de seu narrador, Luis Chato, para saber "que imagens da mulher, representada pela personagem Mariana, aparecem no romance e como essa representação se relaciona com a sua especificidade de mulher das comunidades rurais da Amazônia" (SOUZA, 2016a, n. p.). Já no segundo, ele

\footnotetext{
${ }^{7}$ Arão Bentes (2015, p. 124), em sua dissertação de mestrado, inseriu uma prova documental, que é a foto do túmulo de Paulo Jacob no Cemitério São João Batista, em Manaus (AM).
} 
Gabriel Arcanjo Santos de Albuquerque

aborda o sagrado naquela que também é chamada de a Amazônia dos beiradões, com o intuito de mostrar que, "baseado no sincretismo religioso que veio a se formar a partir da religião cristã e da tradição indígena, o homem deste espaço clama por todos os santos, deuses e entidades mitológicas que podem lhe auxiliar" (SOUZA, 2016b, p. 50).

Como podemos notar, os estudos de Souza sobre Paulo Jacob e a sua ficção se condensam principalmente em Chuva branca. Tanto é assim que a dissertação de mestrado do autor, defendida também em 2016, versou sobre esse romance. Com o título Chuva branca: rastreando a biblioteca amazônica em um romance de Paulo Jacob, o autor investiga a intertextualidade e descobre que:

Em Chuva branca, ao resolver realizar uma representação sobre a Amazônia, o escritor Paulo Jacob inseriu alguns dos temas mais relevantes sobre o modo de vida, dos costumes, das crenças e da maneira de ver as coisas de uma das tipologias do homem amazônico. É certo que Chuva branca, frutificando na seleção, como convém a todo romance, não fala de tudo, mas diz muito sobre o tesouro cultural da Amazônia onde Paulo Jacob viveu e trabalhou durante grande parte de sua vida como magistrado, o que mostra que ele possuía íntima relação com o universo relatado em sua obra (SOUZA, 2016c, p. 109).

Parte dessa dissertação foi publicada em forma de artigo, por Souza, em 2017. Um artigo versando sobre a miséria foi publicado com o seguinte título: Chuva branca: esboço de uma reflexão sobre a miséria humana na Terceira Amazônia, com o objetivo de "mostrar como a miséria humana aparece na narrativa, assim como levantar e discutir algumas das possíveis causas que fazem da miséria a tônica social deste espaço" (SOUZA, 2017a, p. 49). Ainda em outro artigo, sobre a cultura indígena, o autor postula que, dentre os valores que são veiculados nesse romance, está "o corpo tradicional de técnicas, de costumes e de conhecimentos, seja no âmbito da habitação, do transporte, da alimentação e da cozinha, da toponímia e da língua, da medicina natural, da religião, entre outros, que foi repassado, aprendido ou mesmo herdado do ameríndio ou nativo" (SOUZA, 2017b, p. 64).

Em coautoria, Souza publicou com Louro e com Albuquerque. Este último, em 2018, aborda o conteúdo geográfico no romance Um pedaço de lua caía na mata (1990), mostrando imagens literárias do espaço rural e urbano da cidade de Parintins no período de 1850 a 1925, tempo em que se passa a narrativa. Em outras palavras, como 
Gabriel Arcanjo Santos de Albuquerque

os autores apontam, esse é um romance em que "Paulo Jacob mergulha a fundo na história de seu povo na Amazônia para extrair o capital sociocultural, bem como as imagens do espaço urbano e rural com os quais construiu o romance" (SOUZA e ALBUQUERQUE, 2018, p. 13). No outro artigo, de 2014, analisando Chuva branca, Souza e Louro fazem um retrato cultural da Amazônia, mostrando:

O papel do mito na vida e existência do homem amazônico, o qual vem sempre para impedir a sua felicidade e realização. Para tanto, fazse necessário desvendar qual é a concepção cabocla sobre fé e religião cristã, assim como identificar em que resultará a exposição do protagonista Luis Chato à proposta de renovação espiritual sugerida pela nova crença. Descobrir, outrossim, se a quarentena passada na selva provocou, em Luis Chato, alguma espécie de purificação e fez dele um homem melhor. (SOUZA e LOURO, 2014, p. 136-137, grifos nossos).

Uma autora que vem aumentando significativamente as pesquisas sobre Paulo Jacob é Karina Marques, que leciona atualmente na Universidade de Poitiers, França. A pesquisadora, que também investiga sobre identidades judaicas desde o seu doutorado, concluiu em 2018 um pós-doutorado na Universidade Rennes 2, França, sobre a obra de Paulo Jacob. Ela vem trazendo, desde 2017, a sua contribuição aos estudos sobre o escritor com os artigos Parintins, entre a capital e a selva, a cidade flutuante, e também Identidades de gênero e ameríndia: a descolonização do corpo em Robert Lalonde e Paulo Jacob. Neste, trazendo possivelmente a primeira crítica existente sobre Tempos infinitos (1999), a autora faz uma análise comparativa "interamericana" com o romance do escritor canadense Robert Lalond concernente ao "relacionamento intercultural entre índio e brancos, dentro da esfera amorosa" (MARQUES, 2017a, p. 135). Já naquele, Marques lança mão de um conceito proposto por Simon Harel (2006), o "migrant braconnier" (literalmente, "migrante que é caçador furtivo"), "como chave de interpretação para a estratégia de reapropriação territorial proposta por Jacob", unindo autóctones (ameríndios) e alóctones (imigrantes judeus), no romance Um pedaço de lua caía na mata (1990) (MARQUES, 2017b, p. 29).

Em 2018, Marques toma como foco de estudo o romance Vila rica das queimadas (1976), utilizando para a sua análise o conceito de "fronteira-mundi" de Bertha Becker, "a fim de compreendermos a complexidade da Amazônia jacobiana, 
Gabriel Arcanjo Santos de Albuquerque

espaço de entre-dois, entre o local e o global, origem e devir, encarnando o desafio identitário brasileiro e aquele do próprio narrador, Nagib" (MARQUES, 2018, p. 213) ${ }^{8}$. Seu artigo analisa o percurso de imigrantes sírios até a região amazônica, durante a época áurea gomífera, e a relação intercultural dessa comunidade com a população local, realçando o papel social fundamental que eles exerceram, juntamente com os judeus magrebinos, no trabalho como regatões. E, no fim desse mesmo ano, Marques se debruça sobre o romance Dos ditos passados nos acercados do Cassianã (1969) para fazer uma análise comparativa com A selva (1930), do escritor português Ferreira de Castro, descobrindo a existência de "um projeto de reconstrução da história do primeiro ciclo gomífero amazônico, através do olhar de dois personagens exilados: o imigrante português Alberto e o migrante nordestino Raimundo Marcelino" (MARQUES, 2019, p. 280). Ela denuncia ainda, através da invisibilidade da obra jacobiana, os critérios de representatividade da identidade literária nacional brasileira, reivindicando um alargamento das "fronteiras desse espaço para além daquelas políticas ou econômicas". Segundo a autora, incorporar as obras do autor "à "geografia literária" brasileira seria reconhecer uma diversidade linguística e cultural que lhe é intrínseca, eliminando cisões internas" (MARQUES, 2018, p. 280).

É preciso destacar que, assim como Igel, que escreve sobre Paulo Jacob a partir dos Estados Unidos da América, Marques também ajuda a divulgar o nome desse romancista da Amazônia no exterior, a partir da Europa, uma vez que se encontra radicada atualmente na França. Ambas as pesquisadoras possuem ligações com a literatura judaica escrita em língua portuguesa, moram fora do Brasil e escolheram, dentre tantos outros possíveis, pesquisar sobre Paulo Jacob.

Vamos também a Pinto, mostrando que o crítico merece destaque em virtude de seus textos sobre Paulo Jacob, feitos desde 2005. Nesse ano, no texto Literatura amazonense de invenção, ao empreender uma visão panorâmica sobre a ficção escrita no Amazonas, desde Frei Gaspar de Carvajal, passando pelo Clube da Madrugada, ele afirma que a prosa amazonense só voltaria a ter expressão na segunda metade do século $\mathrm{XX}$, e isso por meio de três autores, dentre eles Paulo Jacob:

\footnotetext{
${ }^{8}$ Neste artigo, Marques comete os mesmos dois equívocos de Souza: afirmar que Paulo Jacob possui uma obra composta por 14 romances e apontar 2004 como o ano de seu falecimento.
} 
Jamesclay Almeida de Souza

Karina Marques

Gabriel Arcanjo Santos de Albuquerque

Foi Gaspar de Carvajal o primeiro grande ficcionista do Amazonas. Seu relato fabuloso acerca das índias guerreiras habitantes das margens do Nhamundá inaugurou, em pleno século XVI, a literatura ficcional, e, por extensão, a Literatura Amazonense. Talvez esse acontecimento fantástico tenha inibido nossos prosadores, a tal ponto que a prosa amazonense só volta a ter expressão mais de quatro séculos após, com os romances de Paulo Jacob (Chuva Branca), Márcio Souza (Galvez, o Imperador do Acre) e Milton Hatoum (Relato de um Certo Oriente) (PINTO, 2005, n. p.).

Mais recentemente, em 2011 e em 2014, ele publicou dois outros textos. No primeiro, chamando a atenção para o fato de Paulo Jacob não ter sido ligado ao Clube da Madrugada, ele o aponta como o primeiro escritor amazonense a ensaiar uma projeção nacional: “embora sem qualquer ligação com o Clube, é por essa época que se revela o romancista Paulo Jacob, o primeiro a obter projeção nacional duradoura. Entre seus muitos títulos, destacam-se Chuva branca (1968) e Vila rica das queimadas (1976)" (PINTO, 2011, n. p.). Já no segundo texto, trata-se de Ensaios ligeiros, já apresentado aqui.

\section{PANORAMA DOS ESTUDOS JACOBIANOS: EVOLUÇÃO E PORVIR}

Antes de prosseguirmos comentando mais trabalhos, é importante apresentar alguns dados de periodização. E uma consideração que merece ser feita é que a mediana de todas essas publicações são as pesquisas de Leandro (2014) e de Ribeiro (2014). Isso significa, noutros termos, que $48 \%$ de todas as publicações sobre Paulo Jacob foram produzidas antes da tese de Leandro, assim como iguais $48 \%$ foram produzidas depois daquela de Ribeiro. Leandro, investigando sobre ciclos ficcionais da borracha e memorial literário, afirma:

Outro traço importante para anotar na história comparada da literatura amazônica é que, nesse período histórico, pode-se ainda se deparar com narrativas prenhes de motivos semelhantes à do primeiro ciclo da borracha, como em Paulo Jacob (Muralha verde, 1964) e Miguel Jeronymo Ferrante (Seringal, 1972) (LEANDRO, 2014, p. 117). 
Jamesclay Almeida de Souza

Karina Marques
Geografia, Literatura e Arte, v.1, n.2, p. 172-200, jul./dez.2018

DOI: 10.11606/issn.2594-9632.geoliterart.2018.174373

Gabriel Arcanjo Santos de Albuquerque

Ribeiro ${ }^{9}$, em sua tese defendida em 2014 sobre a crítica literária produzida por Assis Brasil, menciona o escritor amazonense cinco vezes, numa delas dizendo que "a produção de Paulo Jacob (1921-2004), apesar de ovacionada na crítica assisiana, não ultrapassa muito, na atualidade, as fronteiras do estado do Amazonas" (RIBEIRO, 2014, p. 42). Apesar de ainda pouco estudada e conhecida fora dos limites do seu estado natal, como afirma Ribeiro, os estudos publicados demonstram que as pesquisas sobre a ficção do escritor vêm crescendo nos últimos anos. De 1968, ano em que surge a primeira crítica sobre Chuva branca, até Leandro (2014) são 46 anos e 27 publicações. A partir de 2005, começamos a ver um interesse maior por parte dos pesquisadores em observar a obra jacobiana.

Dentre esses trabalhos anteriores a 2014, encontra-se a obra Amazônia: Mito e Literatura, em que Marcos Frederico Krüger, professor da Universidade Federal do Amazonas, apresenta Paulo Jacob como autor de livros que compõem o cânone regional, dando como exemplo o título Assim contavam os velhos índios ianõnãmes: "e deve-se considerar ainda Paulo Jacob, com a mitologia indígena recriada em obras diversas, especificamente em Assim contavam os velhos índios ianõnãmes. Se não esgotamos o cânone - nem seria possível fazê-lo [...]” (KRÜGER, 2003, p. 14).

Em 2006, temos a dissertação de Lucilene Lima, defendida pela Universidade Federal do Pará e publicada três anos após sob o título Ficções do ciclo da borracha: A selva, Beiradão e $O$ amante das amazonas. Nesse estudo comparativo de romances do ciclo da borracha, a autora aponta o escritor amazonense como pioneiro em quebrar o estereótipo de crueldade do seringalista, apresentando-o na sua complexidade humana: “Anastácio Trajano, a personagem do seringalista [do romance Cassianã...], foge em mais de um ponto ao tipo inescrupuloso, determinado em outras obras, pois cumpre as obrigações patronais, inclusive o pagamento do saldo aos seringueiros" (LIMA, 2009, p. 124). A autora nota ainda o olhar inovador do escritor ao situar a ação de $O$ gaiola tirante rumo do rio da borracha (1987) "inteiramente a bordo de um barco, o gaiola "Rio Curuçá", além de uma abordagem do ciclo gomífero "que se afasta do usual binômio margem/centro do seringal", diluindo as tradicionais relações de poder entre seringalistas e seringueiros, pois nesse espaço de entre-dois o comandante da

\footnotetext{
${ }^{9}$ Ribeiro comete um erro quanto ao ano de falecimento do escritor, apontando-o como 2004: "a produção de Paulo Jacob (1921-2004)” (RIBEIRO, 2014, p. 42).
} 
Jamesclay Almeida de Souza

Karina Marques
Geografia, Literatura e Arte, v.1, n.2, p. 172-200, jul./dez.2018

DOI: 10.11606/issn.2594-9632.geoliterart.2018.174373

Gabriel Arcanjo Santos de Albuquerque

embarcação é que a assume a voz da autoridade (LIMA, 2009, p. 105). E, ainda em 2006, temos Peres citando Malcolm Silverman, crítico literário e ex-professor do College of Arts and Letters da Universidade Estadual de San Diego, a respeito de Paulo Jacob: "Dalcídio Jurandir (1909-1979) e Paulo Jacob (nascido em 1923 ${ }^{10}$ ) destacam-se com relação à região amazônica e à documentação das condições miseráveis dos habitantes locais" (SILVERMAN, 2000, p. 230 apud PERES, 2006, p. 27).

Um fato que podemos observar é que estudos sobre o escritor paraense Dalcídio Jurandir frequentemente fazem um paralelo com o seu par amazonense, como na tese de Nunes: "como se percebe, Malcolm Silverman destaca, no contexto (da Amazônia como fonte temática do "romance regionalista-histórico"), além do escritor paraense, o amazonense Paulo Jacob, colocando-os num mesmo patamar, ao menos no que diz respeito à 'denúncia documentarista"” (NUNES, 2007, p. 32).

Destaque igualmente para um dos primeiros artigos a fazer uma análise do estilo linguístico de Chuva branca, que é o de Louro. Neste trecho, sobre a textualização, a autora afirma: "Paulo Jacob faz uso de uma linguagem simples, coloquial, espontânea. No seu romance há uma preocupação de resgate do falar amazônico. Faz uso farto de neologismos, recria palavras novas, nisso ele foi comparado em muitos aspectos, como copiador de Guimarães Rosa" (LOURO, 2007, p. 80).

Em seu estudo sobre a pesca na Amazônia, em 2008, Fonseca menciona a palavra moqueado, presente no dicionário publicado por Paulo Jacob: "manteve -se no português do Brasil, mas conjugada, em Jacob (1985, p. 109), moqueado = assado ao moquém ou moquear = assar" (FONSECA, 2008, p. 218). Ainda nesse ano, Silva defendeu sua tese, por meio da qual investigou a identificação e exame de imagens da natureza amazônica presentes na produção ficcional amazonense do século XX. Nela, o autor comenta dois artigos de Arthur Engrácio, nos quais, ao mesmo tempo em que critica "a clara influência de Guimarães Rosa na construção dos textos [de Paulo Jacob]" (SILVA, 2008, p. 122), Engrácio elogia o talento do escritor magistrado: "estas palavras gostaríamos de repetir, agora, ao escritor Paulo Jacob, cujo elogiável talento de romancista dá-lhe condições de abrir o seu próprio caminho, criar sua própria técnica, sem precisar mais de apadrinhamentos ou influências" (ENGRÁCIO, 1995, p. 33).

${ }^{10}$ Como percebemos, Silverman se equivoca quanto ao ano de nascimento de Paulo Jacob. A data correta é 22 de fevereiro de 1921 (Cf. BENTES, 2015, p. 124). 
Jamesclay Almeida de Souza

Karina Marques
Geografia, Literatura e Arte, v.1, n.2, p. 172-200, jul./dez.2018

DOI: 10.11606/issn.2594-9632.geoliterart.2018.174373

Gabriel Arcanjo Santos de Albuquerque

Existem poucos estudos sobre os mitos presentes na ficção de Paulo Jacob. Aguiar, entretanto, em seu artigo em que compara os contos "O tartaruga" (1963), de Benjamin Sanches, e "O pássaro japiim" (1995), de Paulo Jacob, apoia-se nos aportes teóricos do mitólogo Mircea Eliade para comentar um dos mitos presentes na compilação de lendas Assim falavam os velhos índios ianõnãmes, ressaltando que "na narrativa de Paulo Jacob a fronteira homem versus animal volatiza-se mais profundamente que no conto de Sanches. As passagens em que humanos e animais dialogam revelam um universo mágico, delineado em todo o conto" (AGUIAR, 2011, p. 9).

Cabe apontar que, nos últimos cinco anos, vários pesquisadores também apresentaram trabalhos sobre Paulo Jacob em eventos acadêmicos. Em 2015, no XIV Congresso Internacional da Abralic, falando sobre a "necessidade premente da posse da mulher" associada à realidade do seringal (NOGUEIRA, 2015, n. p.), Nogueira cita o romance Dos ditos passados nos acercados do Cassianã. E, em 2016, durante o VIII Colóquio Internacional "As Amazônias, as Áfricas e as Áfricas na Pan-Amazônia”, Lobregat analisa o romance A noite cobria o rio caminhando, com a proposta de “investigar a representação que Paulo Jacob constrói na obra, considerando seu aspecto de denúncia e ao mesmo tempo de construção de um ambiente urbano que revela várias práticas atrozes de realidade" (LOBREGAT, 2016, n. p.).

Alguns trabalhos que já abordaram sobre tropicologia também fizeram referência a Paulo Jacob. Em seu artigo Leandro Tocantins e a amazonotropicologia, Ribeiro ressalta que a proposta de uma ciência que estudasse a adaptação ecológica do homem ao trópico úmido, tal como formulada pelo historiador paraense, já vinha "se expressando na esfera literária desde Simá, considerado por muitos o primeiro romance amazônico; em A Selva, de Ferreira de Castro; nos romances de Dalcídio Jurandir e de Paulo Jacob" (RIBEIRO, 2015, p. 37). Ainda em 2015, Morga e Lage, discorrendo sobre a presença das mulheres nos seringais amazônicos, tecem encômios a respeito do talento de Paulo Jacob para apresentar, em linguagem literária, os barracões dos seringais: "o romancista Paulo Jacob, ao descrever o seringal Andirá consegue expressar de forma brilhante como eram estes barracões e seu entorno" (MORGA e LAGE, 2015, p. 101). 
Gabriel Arcanjo Santos de Albuquerque

Semelhantemente a Morga e Lage, Sá ${ }^{11}$ também se debruça sobre a ficção de Paulo Jacob para investigar o universo dos seringueiros. Os romances jacobianos que tratam do ciclo da borracha são quatro: Andirá (1965), Dos ditos passados nos acercados do Cassianã (1967), O gaiola tirante rumo do rio da borracha (1987) e Tempos infinitos (1999). Sá, ao analisar o segundo dessa lista, expressa que:

Paulo Jacob, com seu romance, nos leva ao interior de um mundo dito civilizado e dito bárbaro simultaneamente pouco visível à exterioridade na densa floresta. Ali as relações de poder não obedeciam a nenhuma legalidade a não ser àquela determinada pelos jogos tácitos entre os senhores dos seringais, imigrantes, foragidos e os políticos da região (SÁ, 2016, p. 134).

E, com base no que observamos, demonstrando que, nos estudos sobre a ficção de Paulo Jacob, predomina o interesse por Chuva branca, Sousa ${ }^{12}$ investigou, em artigo publicado em 2017, tensões coloniais no romance:

Ainda que timidamente, é possível deparar-se com a imbricação entre sujeito e natureza subsistindo os valores e a hierarquias eurocêntricas. [...] Há rastros em Chuva Branca com certa audácia de um embate com a instituição de verdade propagada e institucionalizada sobre a mata, sobre a religião cristã, absorvidos no processo decolonização [...] do imaginário e da memória sociais. Ao vivenciar dois mundos, $\mathrm{o}$ autor nos mostra a dificuldade do protagonista lidar com os referenciais 'civilizados' pelos quais fora educado, despindo-se visceralmente e só assim sobreviver às intempéries da mata (SOUSA, 2017, p. 239).

No mesmo ano, em projeto desenvolvido pela professora Rita Barbosa de Oliveira, a Universidade Federal do Amazonas procurou resgatar e evidenciar escritores amazonenses, organizando uma série de textos sobre eles. O resultado foi a publicação de A literatura no Amazonas (1954-2010), no qual temos um artigo sobre Paulo Jacob,

\footnotetext{
${ }^{11}$ Sá comete o mesmo erro em relação ao ano de falecimento de Paulo Jacob. A autora erra, por uma ampla margem, essa data ao afirmar que "falecido em 1990, o autor neste romance" (SÁ, 2016, p. 133).

${ }^{12}$ Sousa comete dois equívocos nesse artigo: grafar o nome do protagonista de Chuva branca com "z", "Luiz Chato", quando o correto é com "s" "Luis Chato" (Cf. JACOB, 1968, p. 28). E o segundo é afirmar que esse romance foi publicado em 1967 (ano em que concorreu ao Walmap e ficou em quarto lugar), quando o ano correto da publicação é 1968, como a autora mesmo registra: "Chuva Branca, romance do amazonense Paulo Jacob (1968), é tido como obra literária de destaque na Amazônia" (SOUSA, 2017, p. 236).
} 
Jamesclay Almeida de Souza Geografia, Literatura e Arte, v.1, n.2, p. 172-200, jul./dez.2018

Karina Marques

DOI: 10.11606/issn.2594-9632.geoliterart.2018.174373

Gabriel Arcanjo Santos de Albuquerque

escrito por Louro. Nele, a autora afirma que escolheu escrever sobre o escritor "para pôr em evidência o artifício da linguagem, que propõe as astúcias, a cultura, o conhecimento da fauna e da flora, a capacidade de sobrevivência do homem interiorano na floresta da Amazônia. Luis Chato encarna o herói emblemático desse discurso" (LOURO, 2017, p. $33)$.

$\mathrm{O}$ estado da arte que aqui quisemos realizar aponta para lacunas a serem preenchidas nos estudos jacobianos. Enquanto que o romance Chuva branca conta com um número não desprezível de pesquisas, pelas razões já assinaladas, muitos romances do autor ainda não foram tomados como objeto de estudo, tais como Muralha verde (1964), Estirão de mundo (1979), O coração da mata, dos rios, dos igarapés e dos igapós morrendo (1991) e Amazonas, remansos, rebojos e banzeiros (1995). Além disso, obras como Chãos de Maíconã (1974), incluindo um vocabulário da língua ianomâmi, e a coletânea de lendas Assim contavam os velhos índios ianõnãmes (1995) carecem de análises focadas na língua e na cultura dessa etnia ameríndia. O conjunto da produção jacobiana se presta ainda a um estudo sociolinguístico aprofundado sobre o falar regional amazônico, sendo o Dicionário da língua popular da Amazônia um recurso considerável para as pesquisas nessa área.

Alinhado ao objetivo maior ao qual nos propusemos com a realização deste trabalho, Rogel Samuel, na sua súmula intitulada "PAULO JACOB", levanta, por fim, um grave problema associado ao esquecimento do autor na cena literária brasileira. Ensaísta, antigo professor da Universidade Federal do Rio de Janeiro, também manauara de origem judaica e romancista das ficções da borracha, Samuel partilha com Jacob o mesmo olhar de entre-dois sobre a região amazônica. Seu texto breve, sincopado, publicado em seu próprio blog literário, contornando as barreiras dos circuitos editoriais e acadêmicos convencionais, é aquele que melhor sintetiza a importância da obra jacobiana e a urgência imposta à sua difusão:

Sob vários aspectos, ele é o maior romancista da Amazônia. Não é muito lido, conhecido, porque autor difícil, sofisticado. Sua morte não chamou a atenção. Não se soube. Sua morte [...] abre questão grave quanto à divulgação da cultura nacional brasileira. Eu mesmo, amazonense de Manaus, onde morava o escritor, não tive 
Jamesclay Almeida de Souza

Karina Marques

Gabriel Arcanjo Santos de Albuquerque

conhecimento $^{13}$. [...] A casa, em frente ao igarapé, exibe a vocação de Paulo Jacob. Em Manaus, mas sempre voltado para a Floresta. [...] Em Chuva branca, o personagem vai-se adentrando, vai-se assimilando na floresta, vai-se afastando da civilização, até que no fim parece que nem existiu - vira mito. No fim, na morte, ele tira a roupa, fica nu, perdido na mata, integrado nela, sabendo que vai morrer, perdido e integrado, mitificado (SAMUEL, 2008, n. p.).

Autor e obra parecem entrar em ressonância neste texto de Rogel Samuel, relacionando a questão do esquecimento de Paulo Jacob a um problema maior e mais profundo de descaso nacional com relação à cultura amazônica, ou seja, com relação a uma parte intrínseca da própria cultura brasileira, diretamente associada a um imaginário idealmente construído de brasilidade. Sendo a Amazônia uma questão geopolítica, científica e ecológica de interesse e responsabilidade internacionais, o conhecimento da obra jacobiana adquire um caráter ainda mais necessário e urgente. Nesse sentido, a mitificação de Luís Chato, perdido no coração da floresta, torna-se aqui uma metáfora pungente usada por Samuel, que apela para esse adentrar na obra jacobiana, um convite à despossessão dos nossos referenciais espaciais, culturais e linguísticos para acolher essa parte do "complexo amazônico" que nos cabe a todos. A intensificação das pesquisas acadêmicas brasileiras e internacionais sobre o autor, nos últimos anos, pode ser compreendida como uma resposta positiva a esse apelo, ainda que não suficientemente atendido em escala nacional.

\section{CONSIDERAÇÕES FINAIS}

Após a realização deste primeiro estado da arte das pesquisas sobre Paulo Jacob e a sua ficção, podemos observar três períodos distintos: um primeiro que compreende as décadas de 60 e 70 diretamente associado ao prêmio Walmap e aos galardões nele recebidos por Paulo Jacob, com intenso reconhecimento do escritor pela crítica nacional e regional; um segundo, marcado pelo silenciamento pós-Walmap, percorrendo toda a carreira do autor até a publicação de seu último livro, Tempos infinitos (1999); e um terceiro, a partir dos anos 2000 até os dias atuais, caracterizado por um grande interesse

\footnotetext{
13 Tal fato parece explicar a dificuldade encontrada pelos pesquisadores em apresentar a data correta de falecimento do autor.
} 
Gabriel Arcanjo Santos de Albuquerque

sobre a obra jacobiana, por parte de pesquisadores ligados, sobretudo, a instituições do norte do Brasil e internacionais (americanas e francesas).

O primeiro grupo interessa-se, predominantemente, por uma análise de cariz sócio-histórico, centrada nos problemas inerentes ao espaço amazônico. Esses pesquisadores preocupam-se, ainda, em fazer dialogar a obra jacobiana com uma herança literária regional. O segundo foca-se numa perspectiva mais intercultural, estabelecendo relações entre a região amazônica e espaços extranacionais, guiados pelos fluxos migratórios de povos árabes e judeus que marcaram a região durante o início do século XX. Neste sentido, tais estudiosos refletem sobre os pares dicotômicos interior/exterior, local/universal, identidade/alteridade, representados na obra do escritor, utilizando-os, inclusive, como base para questionar a excentricidade e a marginalização da região amazônica - e de sua literatura - dentro do corpo social brasileiro.

Esse duplo interesse acadêmico cumpre um papel extremamente importante para o resgate, a valorização e a legitimação do autor como parte do "cânone amazônico", nos termos de Krüger, e de reivindicação de sua incorporação de jure naquilo que Jorge Amado chamou de "geografia literária" brasileira. Neste sentido, nosso trabalho evidencia que os estudos sobre a obra jacobiana ainda não despertaram o interesse alargado de estudiosos de outras regiões do Brasil, apesar de terem ultrapassado as próprias fronteiras do território nacional.

Neste ano em que se comemora os 20 anos de publicação de Tempos infinitos (1999), observa-se, portanto que, apesar, da recrudescência das pesquisas sobre o autor nos últimos anos, a preocupação de divulgação e de preservação do esquecimento da obra jacobiana, expressa na súmula de Rogel Samuel, ainda é legítima. Isso assume contornos tanto mais urgentes se considerarmos a dificuldade de aquisição da obra do autor em livrarias e bibliotecas, espalhadas pelo território nacional. Fora de circulação do mercado editorial, muitos de seus livros possuindo apenas uma edição, não tendo sido distribuídos em toda a extensão do território nacional, os textos jacobianos tendem a desaparecer, subsistindo substancialmente apenas em bibliotecas do Amazonas ou em acervos de colecionadores de obras raras. 
Gabriel Arcanjo Santos de Albuquerque

\section{REFERÊNCIAS}

AGUIAR, Adriana. Entre cobras e lagartos... aves e quelônios: a permanência do universo zoomítico na literatura produzida no Amazonas. Anais do SILEL, v. 2, n. 2, Uberlândia, 2011. <http://www.ileel.ufu.br/anaisdosilel/wpcontent/uploads/2014/04/silel2011_1678.pdf>. Acesso em: 1/2/2019.

BATISTA, Djalma. O Complexo Amazônico. Rio de Janeiro: Conquista, 1976.

BENTES, Arão do Nascimento. Chuva branca caía em Chãos de Maíconã: a trilogia de Paulo Jacob. 2015. 126p. Dissertação (Mestrado em Letras e Artes - Estudos Literários) - Programa de Pós-Graduação em Letras e Artes, Universidade do Estado do Amazonas.

BRASIL, Assis. Por uma linguagem literária. Correio da Manhã, Rio de Janeiro, 14/07/1968, $4^{\circ}$ Caderno, p. 44.

ESTEVES, Antônio R. Chuva branca: um estudo sobre literatura amazonense contemporânea. 1990. 136p. Dissertação (Mestrado em Letras - Estudos Literários), Instituto de Biociências, Letras e Ciências Exatas, Universidade Estadual Júlio de Mesquita Filho - UNESP.

ENGRÁCIO, Arthur. Os tristes. Manaus: Imprensa Oficial do Estado, 1995.

FERREIRA, Norma Sandra de Almeida. As pesquisas denominadas 'estado da arte. Educação \& Sociedade, ano XXIII, no 79, agosto/2002. <http://www.scielo.br/pdf/es/v23n79/10857.pdf>, acesso em: 15/01/ 2019.

FONSECA, Dante Ribeiro da. A pesca na Amazônia: da pré-colônia ao mundo colonial (séculos XVII ao XIX). Saber Científico, Porto Velho, 1 (2), p. 201-222, jul./dez., 2008.

IGEL, Regina. Brazil: Novels. In: BOUDON, Lawrence; McCANN, Katherine D. (Orgs). Handbook of Latin American Studies: a selective and annotated guide to recent publications in Art, History, Literature, Music, Philosophy, and Electronic Resources. Austin: University of Texas, 2002.

Um espertalhão na Amazônia. ASA, Rio de Janeiro, ano 24, n. 145, novembro/dezembro de 2013. <http://asa.org.br/wp/boletim/ed145/um-espertalhao-naamazonia/>. Acesso em: 20 jan. 2019.

Moacyr Scliar e Milton Hatoum: semelhanças e diferenças. Arquivos Maaravi. Revista Digital de Estudos Judaicos da UFMG, Belo Horizonte, v. 6, n. 11, 2012. <http://dx.doi.org/10.17851/1982-3053.6.11.93-97>. Acesso em: 23 jan. 2019. 
Jamesclay Almeida de Souza

Karina Marques
Geografia, Literatura e Arte, v.1, n.2, p. 172-200, jul./dez.2018

DOI: 10.11606/issn.2594-9632.geoliterart.2018.174373

Gabriel Arcanjo Santos de Albuquerque

JACOB, Paulo. Dicionário da língua popular da Amazônia. Rio de Janeiro: Cátedra, 1985 .

KRÜGER, Marcos Frederico. Amazônia: Mito e Literatura. Manaus: Editora Valer, 2003.

LEANDRO, Rafael Voigt. Os ciclos ficcionais da borracha e a formação de um memorial literário da Amazônia. 2014. 221p. Tese (Doutorado em Literatura Brasileira) - Programa de Pós-Graduação em Literatura, Universidade de Brasília.

LIMA, Lucilene Gomes. Estudo comparativo dos romances A selva, Beiradão e $O$ amante das amazonas. 2006. 127p. Dissertação (Mestrado em Letras - Estudos Literários) - Programa de Pós-Graduação em Letras, Universidade Federal do Pará.

Ficções do ciclo da borracha: A selva, Beiradão e $O$ amante das amazonas. Manaus: Editora da Universidade Federal do Amazonas, 2009.

LOBREGAT, Maria Cristina. A noite cobria o rio caminhando: uma narrativa que pulsa a visão do inacabado em espaços amazônicos. In: COLÓQUIO INTERNACIONAL AS AMAZÔNIAS, AS ÁFRICAS E AS ÁFRICAS NA PAN-AMAZÔNIA, VII, 2016, Rio Branco. <http://revistas.ufac.br/revista/index.php/simposioufac/article/view/806>. Acesso em: 1 fev. 2019.

LOURO, Francisca de Lourdes Souza. A significação social da Amazônia no romance Chuva Branca de Paulo Jacob. Novum Millenium, Manaus, v. 5, 2007, p. 72-78.

Chuva branca no universo de Paulo Jacob. In: OLIVEIRA, Rita do Perpétuo Socorro Barbosa de ; SANTOS, José Benedito ; AZEVEDO, Kenedi Santos (Orgs.), A literatura no Amazonas (1954-2010). Rio de Janeiro: Letra Capital, 2017, p. 32-48.

MACEDO, Vera Amália Amarante. Dicionários. In: CAMPELLO, Bernadete Santos, CALDEIRA, Paulo da Terra (Orgs). Introdução às fontes de informação. Belo Horizonte: Autêntica Editora, 2008, p. 23-42.

MARQUES, Karina Carvalho de Matos. Identidades de gênero e ameríndia. A descolonização do corpo em Robert Lalonde e Paulo Jacob. Interfaces Brasil/Canadá, Florianópolis/Pelotas/São Paulo, v. 17, n. 3, 2017a, p. 135-154. $<$ https://periodicos.ufpel.edu.br/ojs2/index.php/interfaces/article/view/12407>. Acesso em: 24 jan. 2019.

A Amazônia de Paulo Jacob: as fronteiras da 'fronteira-mundi'. Aletria, Belo

Horizonte, v. 28, n. 2, 2018, p. 213-231. 
Gabriel Arcanjo Santos de Albuquerque

Portugal amazônico de Ferreira de Castro e a Amazônia nordestina de Paulo Jacob: Um olhar de entre-dois sobre a terra natal. Cadernos de Literatura Comparada, Porto, n. 39, v. $12, \quad 2019, \quad$ p. 257-284. <http:/dx.doi.org/10.21747/21832242/litcomp39v2>. Acesso em: 24 jan. 2019.

Parintins, entre a capital e a selva, a cidade-flutuante. $R E-U N I R$, v. $4, \mathrm{n}^{\circ} 2$, 2017b, p. 29-48. <http://www.periodicos.unir.br/index.php/REUNIR/article/view/2448>. Acesso em 24 jan. 2019.

MENEZES, Armando de. Imponderável silêncio, Manaus: Academia Amazonense de Letras, 2011.

MONTEIRO, Mario Ypiranga. Fatos da literatura amazonense. Manaus: Universidade do Amazonas, Instituto de Ciências Humanas, 1976.

MORGA, Antonio Emilio; LAGE, Mônica Maria Lopes. Mulheres nos seringais do Amazonas: sociabilidade e cotidiano. Revista Latino-americana de Geografia e Gênero, Ponta Grossa, v. 6, n. 1, jan. / jul. 2015, p. 91 - 104. <http://revistas2.uepg.br/index.php/rlagg/article/viewFile/6603/pdf_157>. Acesso em: 3 jan. 2019.

NOGUEIRA, Francisco dos Santos. A transa amazônica e sua marginalização segundo Alberto Rangel. In: CONGRESSO INTERNACIONAL DA ABRALIC, XIV, 2015, Belém, Anais Eletrônicos. <http://www.abralic.org.br/anais/arquivos/2015_1455988740.pdf>. Acesso em: 2 fev. 2019.

NUNES, Paulo Jorge Martin. Útero de areia, um estudo do romance 'Belém do GrãoPará', de Dalcídio Jurandir. 2007. 196p. Doutorado (Literaturas de Língua Portuguesa) - Programa de Pós-Graduação em Letras, Pontifícia Universidade Católica de Minas Gerais.

OLINTO, Antonio. O sertão de Rosa. Tribuna da imprensa. Rio de Janeiro: 16 jan. 2007.

Uma história que flui. In: CELINA, Lindanor. Breve Sempre. Belém: Governo do Estado do Pará, 1973.

PERES, Carlos Roberto Cardoso. Linha do Parque, de Dalcídio Jurandir: romance histórico, social e proletário (a gênese do movimento operário no Extremo Sul do Brasil). 2006. 161p. Dissertação (Mestrado em História da Literatura) - Programa de Pós-Graduação em Letras, Fundação Universidade Federal do Rio Grande.

PINTO, Zemaria. Ensaios ligeiros. Manaus: Governo do Estado do Amazonas Secretaria de Estado de Cultura, 2014. 
Gabriel Arcanjo Santos de Albuquerque

<http://www.jornaldepoesia.jor.br/zpinto07c.html>. Acesso em: 23 jan. 2019.

Literatura amazonense de ficção: referências (2011). Disponível em: <http://palavradofingidor.blogspot.com/2011/11/literatura-amazonense-de-ficcao.html>. Acesso em: 22 jan. 2019.

RIBEIRO, Francigelda. Caminhos da crítica e da literatura sob a perspectiva de Assis Brasil. 2014. 233p. Tese (Doutorado em Estudos Literários) - Departamento de Teoria Literária e Literaturas, Universidade Federal de Minas Gerais.

RIBEIRO, Odenei de Souza. Leandro Tocantins e a amazonotropicologia. TEXTOS\&DEBATES, Boa Vista, n.27, v.1., jan./jun. 2015, p. 33-42. <https://revista.ufrr.br/textosedebates/article/view/2836>. Acesso em: 30 jan. 2019.

SÁ, Sônia Maria Neves Bittencourt de. As coisas e seus agenciamentos no universo dos seringueiros no romance Dos ditos Passados em Cassianã de Paulo Jacob. Gaia Scientia, Edição Especial Cultura, Sociedade \& Ambiente. Volume 10(1): p. 133-144, 2016. <http://periodicos.ufpb.br/ojs/index.php/gaia/article/view/30364/16060>. Acesso em: 3 fev. 2019.

SILVA, Allison Marcos Leão. Representações da natureza na ficção amazonense. 2008. 194p. Tese (Doutorado em Estudos Literários) - Programa de Pós-Graduação em Letras, Universidade Federal de Minas Gerais.

SOUSA, Maria de Nazaré Cavalcante de. Tensões (de)coloniais em Chuva branca, de Paulo Jacob. Muiraquitã, Rio Branco, v. 5, n. 1, 2017, p. 236-243. <http://revistas.ufac.br/revista/index.php/mui/article/download/1390/847>. Acesso em: 3 fev. 2019.

SOUZA, Jamescley Almeida de. Paulo Jacob: uma fortuna crítica. Revista Eletrônica de Literatura O Guari, União da Vitória, 2015a. <http://oguari.blogspot.com/p/paulojacob-uma-fortuna-critica.html>. Acesso em: 22 jan. 2019.

Chuva branca: esboço de uma reflexão sobre a miséria humana na Terceira Amazônia. Revista Elaborar, Manaus, v. 4, n. 1, mar. 2017a, p. 49-73. <http://periodicos.ufam.edu.br/revistaelaborar/article/view/3421>. Acesso em: 24 jan. 2019.

Chuva branca: rastreando a biblioteca amazônica em um romance de Paulo Jacob. 2016c. 116p. Dissertação (Mestrado em Letras - Estudos Literários) - Programa a de Pós-Graduação em Letras, Universidade Federal do Amazonas. 
Gabriel Arcanjo Santos de Albuquerque

Da questão de gênero no romance Chuva branca. Revista Eletrônica de Literatura O Guari, União da Vitória, 2016a. <http://oguari.blogspot.com/p/daquestaode-genero-no-romance-chuva.html>. Acesso em: 18 jan. 2019.

Do sagrado na Terceira Amazônia: um olhar a partir do romance Chuva

branca. Revista Elaborar, v. 3, n. 1, fev. 2016b, p. 50-70. <http://www.periodicos.ufam.edu.br/revistaelaborar/article/view/1706>. Acesso em: 24 jan. 2019.

Personagens do imaginário ribeirinho no romance Chuva branca. Revista Decifrar, Manaus, [s.l.], v. 3, n. 6, nov. 2015b, p. 114-132. <http://periodicos.ufam.edu.br/Decifrar/article/view/1104>. Acesso em: 24 jan. 2019.

. Uma preleção sobre a heurística indígena: estudo no romance Chuva branca. Revista Elaborar, Manaus, [s.1.], v. 4, ano 5, n. 2, 2017b, p. 63-78. <http://periodicos.ufam.edu.br/revistaelaborar/issue/view/276>. Acesso em: 24 jan. 2019.

SOUZA, Jamescley Almeida de; ALBUQUERQUE, Gabriel Arcanjo Santos de. Imagens do Espaço Rural e Urbano no Romance Um Pedaço de Lua Caía na Mata: A Cidade de Parintins de 1850 a 1925. In: Seminário Internacional em Sociedade e Cultura na Pan-Amazônia-Manaus, 2018. <https://www.doity.com.br/anais/iiisiscultura/trabalho/67375>. Acesso em: 17/01/2019.

SOUZA, Jamescley Almeida de; LOURO, Francisca de Lourdes Souza. Chuva Branca: o retrato cultural da sociedade amazônica brasileira na obra de Paulo Jacob. Revista Decifrar, Manaus, $\quad$ v. $\quad 02, \quad 2014 \quad$ p. $135-151$. <http://www.periodicos.ufam.edu.br/Decifrar/article/view/1043/936>. Acesso em: 30 jan. 2018.

SOUZA, Márcio. A expressão amazonense : do colonialismo ao neocolonialismo. Manaus: Editora Alfa-Ômega, 1978.

TUFIC, Jorge. Literatura amazonense: de Carvajal a Ferreira de Castro. Livrornal, Manaus, v. 1, n. 2, maio de 1978.

Recebido em 05/08/2018.

Aceito em 28/10/2018.

Publicado em 10/09/2020. 